\title{
Dissociative Identity Disorder in Todd Philips' Joker
}

\author{
Arni Eka Putri Wirjayanti ${ }^{1)}$, Ali Mustofa ${ }^{2)}$ \\ ${ }^{1}$ Universitas Negeri Surabaya \\ arni.17020154046@mhs.unesa.ac.id \\ ${ }^{2}$ Universitas Negeri Surabaya \\ alimustofa@unesa.ac.id
}

Received: $9^{\text {th }}$ June 2021| Revised: $23^{\text {rd }}$ October 2021| Accepted: $27^{\text {th }}$ October 2021

Email Correspondence: arni.17020154046@mhs.unesa.ac.id

\begin{abstract}
This study examines a dissociative disorder in the film Joker, which aired in 2019 and was directed by Todd Philip. This study aims to show how Arthur Fleck's character becomes someone who suffers from dissociative identity disorder and what factors cause Arthur Fleck who initially looks fine but turns out to have a different side of him. This study uses Sigmund Freud's psychoanalytic theory, which explained how the conditions of the Id, Ego, and superego in Arthur Fleck are actually the main influences of Arthur's disorder. The results of this study conclude that Arthur Fleck's character immediately changes because of events in his dark past. His past makes Arthur Fleck suffer from disorders such as DID due to the instability of his unstable personality structure.
\end{abstract}

Keywords: psychoanalysis, dissociative identity disorder, personality structure

\section{INTRODUCTION}

We all know that films and novels have their charm for the audience. Sometimes watching movies is more fun because when watching a film, we no longer need to imagine how a character will do something, but we can see firsthand what happens in the film. We can identify something that one character is hiding. According to the Cambridge Dictionary, the film's definition represents a collection of moving images as real as those presented on television or cinema. According to Michael Rabiger (Rabiger \& Hurbis-Cherrier, 2013), the film's meaning will be deeper and interesting so that it can develop the audience to think more deeply.

Movies are almost the same as real life. We can see what costume and colors they are wearing, what the characters in the film show facial expressions, what dangerous gestures are depicted, depictions of bad or nice people, and other things that we cannot get when reading the novel. According to the author, watching movies is more obvious to people who may not like reading a collection of thick novels. But, reading novels also has its pleasure for those who like novels.

Online at https://journal.universitasbumigora.ac.id/index.php/humanitatis/

DOI : https://doi.org/10.30812/humanitatis.v8i1.1436 
In this study, the author expresses his idea of researching a film that is even predicted to become a film with a large audience since its screening. This film invites the enthusiasm of the audience because the storyline is packaged in an interesting way and provides life lessons for the audience. Not only life lessons, but the audience can learn something from the film that discusses the mental disorders experienced by the main character in this film. Viewers can tell how badly the main character in this film suffers from mental illness. The author refers to the Joker film by Todd Philips which was released in 2019.

This film is an interesting topic to discuss because many people already know about this film. This film is certainly interesting and is known by many people because of the achievements of the actors and directors. Initially, Todd Philips himself was a director who was famous for his comedy films. Todd himself has been working on comedy genre films for a long time, and starting in 2018 he has been producing romance genre films, and in 2019 he tried to work on a film with a cool storyline called Joker. Initially, many doubted that Todd Philips produced Joker.

Research involving the film Joker raises the issue of dissociative identity disorder. Why did the author choose this topic, and what is the full picture of dissociative identity disorder? The author chose this topic because it is quite important for the reader to the author. The author wants the reader to know that a disease like DID should not be taken lightly. These diseases can be fatal and detrimental to many parties, therefore the researcher would like to convey several things related to DID in this study. Dissociative disorder is a mental illness with impaired memory, awareness, identity, and perception (Nugroho, 2013).

These symptoms can interfere with human life functions in general, including work functions, activities, and social relationships. Dissociation is a disorder that anyone can experience, where one uses this method to avoid and escape from stressful situations and traumatic memories. A person uses this method to cut the connection between himself and the outside world and distance himself from the awareness of what is happening. Dissociation can serve as a defense mechanism against physical and emotional pain from traumatic experiences and stress. Some people may have a past that makes them traumatized, whether it's trauma due to torture or even sexual harassment (Trifu, 2019).

What is clear is that such trauma can lead a person to live in darkness and the shadows of a dark past because someone's memory of something painful will be easy to remember. A person will continue to remember how he was hurt so that it is not uncommon for people who have had a sense of trauma since childhood to grow up as someone who will experience mental disorders. It must be because they all influence each other.

Online at https://journal.universitasbumigora.ac.id/index.php/humanitatis/

DOI $\quad$ : https://doi.org/10.30812/humanitatis.v8i1.1436 
The author has linked this interesting topic with the Joker movie, which also has a storyline that falls under the topic chosen by the author. The Joker film tells the story of a street clown named Arthur Fleck. He lives in the middle of Gotham, which is full of chaos, and the city is a mess. Arthur only lived in a small, dimly lit apartment with his mother. Arthur's mother was very old, so Arthur had to take care of his mother from washing to preparing her meals every day. Arthur does look like a good person from the outside, but who knows if Arthur is not a normal person. He has a mental illness that makes him always considered strange by those around him. Why do people think Arthur is weird?

It was all because Arthur suffered from pseudobulbar affect (PBA). This disease causes sufferers to laugh or cry for no reason. The expression described by that person will be contrary to the condition that is actually felt by that person (Ahmed \& Simmons, 2013). That's what happened to Arthur. So many people began to think he was strange to insane. There are so many factors that cause Arthur to lose control because of his mental illness so that another mental disorder such as dissociative identity disorder arises. A person with dissociative identity disorder does not always have multiple personalities. They have at least two personalities that can be said to be different because sometimes they are good people, and sometimes they are bad people, so they can kill people to get their happiness.

This study has two main problems, the first is to show how DID is depicted in the Joker film and the second is to show the factors that make the main character of the Joker film suffer from DID. In this study, the author uses the psychoanalytic theory of Sigmund Freud. Psychoanalytic theory is a theory used to explain the nature and development of human personality. The elements that are prioritized in this theory are motivation, emotions, and other internal aspects. This theory works to reveal how the condition of Arthur Fleck's personality structure which includes the id, ego, and superego. This theory assumes that personality develops when there is a conflict from a psychological aspect (Slochower, 2016). The author argues that Freud's theory is suitable to be the main theory of this research because this theory dissects what is in Arthur's personality.

The author found several studies on DID which also used Freud's psychoanalytic theory using other works and most of these works were from novels and films that were quite old. The author has decided to redevelop DID and psychoanalysis using the latest film, Joker, which has never been discussed anywhere. The author considers this because this can be a new lesson that will add to the world of research in the field of DID using Freud's psychoanalytic theory.

Online at https://journal.universitasbumigora.ac.id/index.php/humanitatis/

DOI $\quad$ : https://doi.org/10.30812/humanitatis.v8i1.1436 


\section{RESEARCH METHOD}

This study uses two theories. The first is Sigmund Freud's psychoanalytic theory. This theory is the main theory of this research, and the author uses the supporting theory of dissociative identity disorder from Elizabeth Howell. This study uses screenshots of several scenes as the main source that is continuous with the theories used. Screenshots are also accompanied by explanations of some scenes that may not be accompanied by dialogue because every meaning of a film does not have to come from dialogue but also from the movements of the actors. For scenes that contain dialogue, any dialogue written by the actor is still given to clarify the meaning and discussion. The author has also used cinematic language to clarify each scene that the author uses for problem solving materials.

\section{FINDINGS AND DISCUSSION}

\subsection{How was dissocitive identity disorder represented in Arthur Fleck}

The first discussion is about how DID is depicted in the figure of Arthur Fleck. In this scene, from 00:33:12 to 00:33:35, Arthur is shown trying to chase after someone who bullied him on the train. With more courage, Arthur began to use his gun to kill the group of men. This scene is not equipped with dialogue but shows directly how Arthur changes, who initially always succumbs when attacked and now becomes a fierce person.

This personality can control the sufferer's body and mind at any time and is usually triggered by certain situations when the sufferer feels stressed, afraid, or angry (Howell \& Itzkowitz, 2016). as was the case with Arthur. Arthur can't control his emotions, so that negative thoughts arise to something scary like killing other people to produce peace within himself.
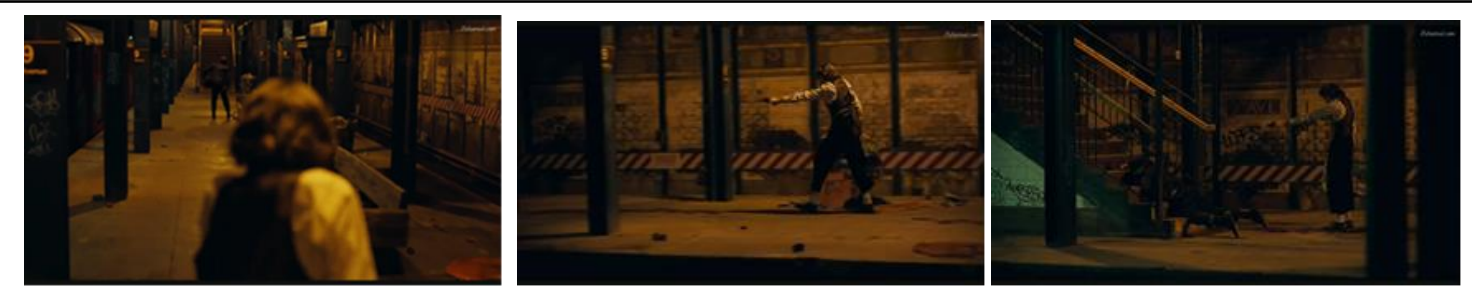

Figure 1. When Arthur shot the guy, who bullied him on the train.

The vibes are even tenser because the murder incident is set in a quiet station and is set with dim lights coupled with a panning shot technique where the camera moves along with Arthur. The technique used to show the entire background of the scene in this scene uses a long shot to clearly see the background of the place to anyone involved in this incident because all objects are included in the camera.

Online at https://journal.universitasbumigora.ac.id/index.php/humanitatis/ 
Arthur was also still in his clown costume, and without removing the makeup on his face, he looked terrible because of his messy makeup because he had to run after the men. The shooting technique used during this scene is a high angle where the point of view is taken higher than the intended object so that the audience can see the object that Arthur is chasing.

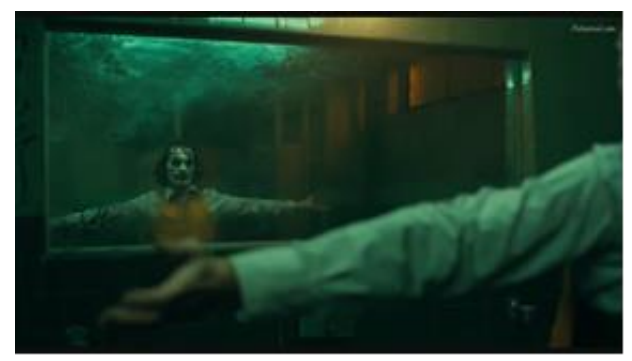

Figure 2. When Arthur danced incoherently in the toilet after he killed.

The scene from 00:34:32 to 00:35:45, it shows that Arthur is in a toilet with dim lights. It was there that he secured himself after killing the men. Elizabeth Howell (Howell, 2012), says that people with dissociative identity disorder are unlikely to remember anything that happened, even if it was a homicide. At first, Arthur did feel very scared and tried to disappear so he wouldn't be caught, but after he tried to calm himself, he would forget everything he did for fun. It will grow tremendous joy when people with DID manage to get rid of someone who hurt them.

The shooting technique in this scene is eye level because the camera is very focused on showing Arthur's face that is exhausted after running to find a hiding place. It wasn't long before Arthur was like an innocent man after killing people. He even danced with incoherent movements. The technique used when recording this scene is a long shot because it shows the audience that Arthur is in the toilet alone and no one is there. The effects used in this scene tend to be dark.
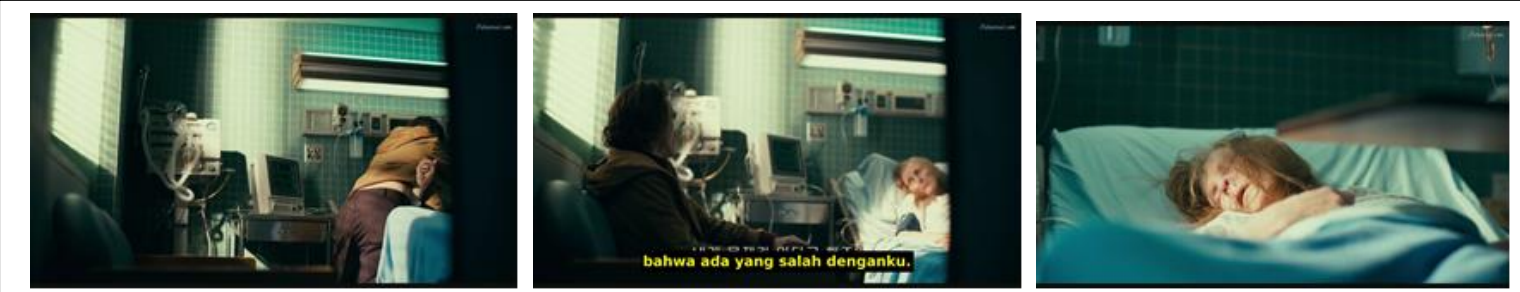

Figure 3. Arthur spoke to his mother, then he killed her.

The scene from 01:19:47 to 1:21:05 shows that Arthur is talking to his mother who is being treated at the hospital.

Online at https://journal.universitasbumigora.ac.id/index.php/humanitatis/

DOI $\quad$ : https://doi.org/10.30812/humanitatis.v8i1.1436 
Arthur: "Hey Penny, what's my real name? Where did I come from? You remember how you used to tell me that God gave me this laugh for a reason? That, that I had a purpose. Laughter and joy, that whole thing. HA! It wasn't God, it was you. Or, or one of your boyfriends, do you even know what my real name is? Do you know who I really am? C'mon, Penny, who am I?

Penny: "Ha... Happ...y

Arthur: "Happy?! I'm not happy. I haven't been happy for one minute of my entire fucking life. But you know what's funny? You know what really makes me laugh? I used to think my life was nothing but a tragedy, but now, now I realize it's all just a fucking comedy.

The dialogue above shows that Arthur's tone of voice has changed because he is emotional and disappointed when he finds out his true past life so he doesn't use the word "Mom" to call his mother but calls her "Penny".

Arthur's expression was set in such a way as if he was holding back his emotions. In taking this scene using light control techniques. This is a technique to increase or decrease the exposure of a light source - this addition or subtraction produces a certain effect. For example, the effect of sunlight shining in on the bedroom window, using a translucent affixed near the light source. And in this scene, light only appeared from the window behind Arthur. The camera continues to focus on the face and movements of Arthur, who is talking to his mother, because the most important object in this scene is the words Arthur says to his mother.

One of the symptoms of someone suffering from DID is depression (Howell \& Itzkowitz, 2016) because of a bad past life. The formation of his soul is not perfect because it is always haunted by anxiety, unstable emotions, to excessive frustration. This is what happened with Arthur, so that he killed his mother because of uncontrolled emotions.

From the dialogue, "I haven’t been happy for one minute of my entire fucking life. But you know what's funny? You know what really makes me laugh? I used to think my life was nothing but a tragedy, but now, now I realize it's all just a fucking comedy" This can be analyzed if Arthur Fleck needs happiness which makes him depressed and frustrated like this. And in the end, he created his happiness by becoming another Arthur who had the heart to kill his mother knowingly, and he even felt relieved. As usual, people with DID will not have the slightest sense of guilt and will immediately forget the incident.

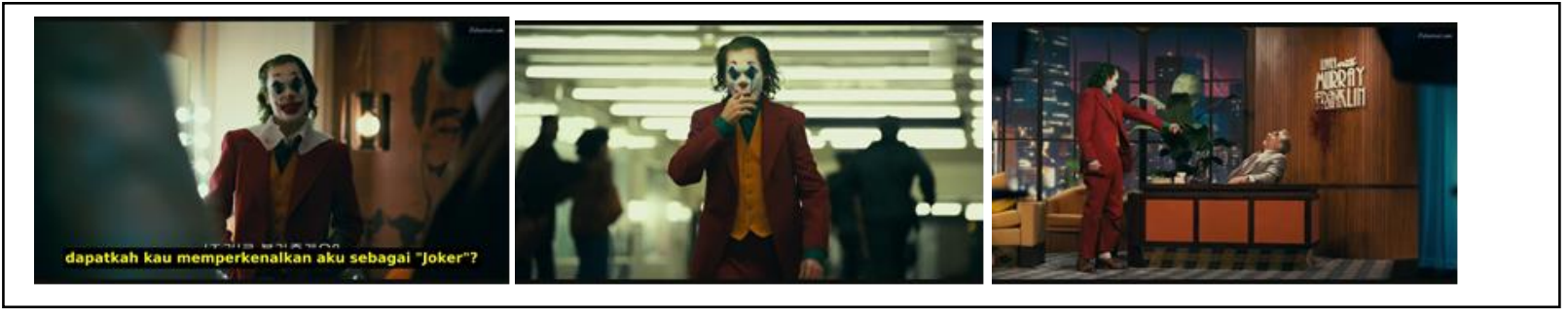

Figure 4: when Arthur has turned into the Joker.

Online at https://journal.universitasbumigora.ac.id/index.php/humanitatis/

DOI : https://doi.org/10.30812/humanitatis.v8i1.1436 
The scenes from 01:34:38 to 01:46:09 show that Arthur has turned into the Joker. He doesn't even want to be called by his real name anymore.

\section{Arthur: "Hey Murray, one small thing? When you bring me out, can you introduce me as Joker?" \\ Gene Ufland: "What? You don't want to use your real name?" Arthur: "Honestly, I don't even know what my real name is.}

From the dialogue above, we can tell if Arthur doesn't want to be himself. He was so vengeful with the name Arthur that from that day on he turned into the evil Joker. It is no longer Arthur who can hold back his anger, but he turns into the Joker who viciously kills the people in the studio.

These are the most fatal attitudes of people with DID. He will not even see the condition where he is, who is dealing with him. What he has in mind is when a person with DID has a long-buried grudge, over time he will vent that grudge without the slightest sense of guilt (Letterio et al., 2020). Arthur's face was even very happy when he managed to fight and kill Murray. People who suffer from DID do not hesitate to kill the life of anyone who is important, he can vent his revenge.

In this scene Arthur's appearance changes. He wears him clown makeup with flashy green hair. He wore a bright red formal dress as well. The expression on his face was very happy as he was about to straighten out his action to destroy the studio where he was invited by Murray. There are several settings in this scene. The first on the streets, trains, to the studio. In this scene, the camera uses a lot of close-up techniques to get Arthur's words. In addition, the camera also takes an angle where Arthur's face is shown like a demon preying on its prey.

\subsection{The factors that cause Arthur Fleck to have dissociative identity disorder}
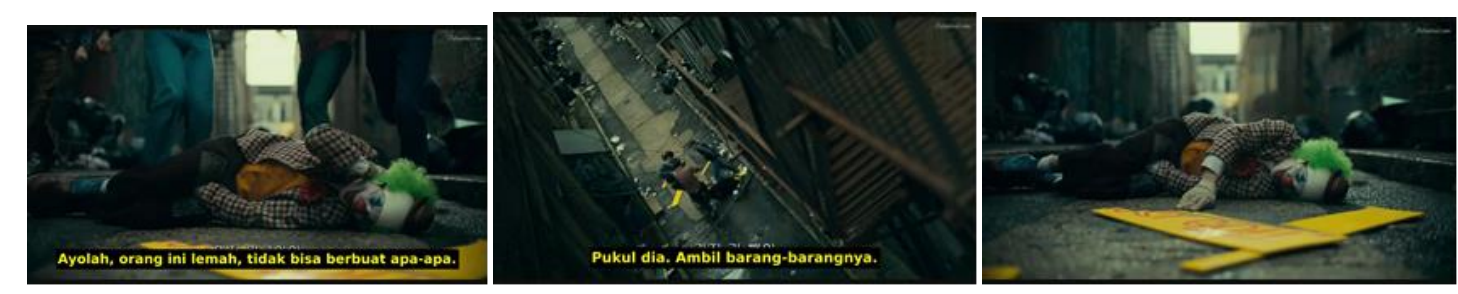

Figure 5. When a group of teenagers molested Arthur.

The scene from 00:02:53 to 00:03:00 shows Arthur being molested by a group of teenagers who stole Arthur's board while Arthur was at work.

Arthur: "Hey stop it..."

1st boy: "F*ck you."

2nd boy: "This is weak people and can do nothing."

Online at https://journal.universitasbumigora.ac.id/index.php/humanitatis/

DOI : https://doi.org/10.30812/humanitatis.v8i1.1436 
Arthur: (covers himself with his hands and just groans in pain)

Another boy: "Hit him and get his stuff."

The dialogue above can be analyzed clearly if an Arthur Fleck can still hold the Ego that is in him. In Freud's psychoanalytic theory (Lapsley \& Stey, 2012), the Ego is referred to as a way of dealing with reality. Reality-based on something that is considered right or wrong according to the views of others. When the children said, "this people weak can do nothing" it was because Arthur could only protect himself without being able to do anything.

The Ego in Arthur Fleck can still be restrained, so he prefers to remain silent and let the children beat him. But when Arthur can't balance his Ego, he can fight the kids. Because after all the ego that is in the human body can lose to the id which is in charge of destroying the ego and superego when the person's mind has to fight something that hurts him and get victory over what he wants (Gupta, 2020). What can be analyzed from the scene above is that Arthur's ID, Ego, superego is still stable and balanced. This is the first factor that Arthur turns into someone who eventually suffers from DID. Initially, he already had a mental disorder, but he was played by life.

Arthur uses a clown costume with vintage-style clothes because the Joker movie was set in 1980 . The background of the place used is the streets of Gotham, which happen to be very busy. Taking pictures of this scene several times using extreme long shots where Arthur, as the main subject, looks small, the camera focuses on the objects there, so the camera shows how the boys treat Arthur.
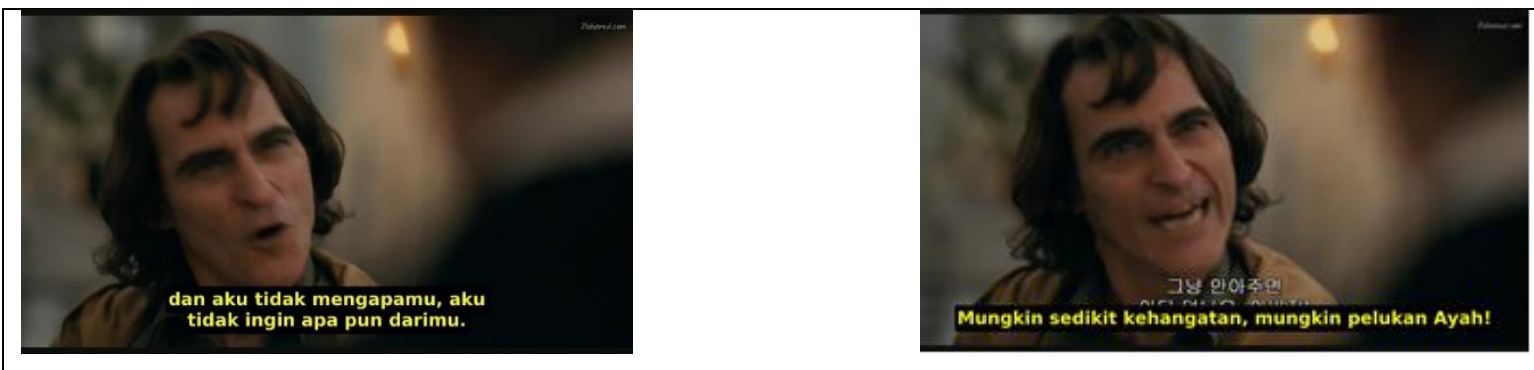

Figure 6. When Arthur ventured to meet Thomas Wayne

In scenes from 01:04:32 to 01:06:45, Arthur comes to the toilet to meet Thomas. He came intending to reveal what he had been hiding. He told Thomas everything, but Thomas instead said something very hurtful to Arthur. In this scene, Arthur wears a slightly shabby brown jacket and oversized jeans. Meanwhile, Thomas Wayne looks neat and luxurious in a black tuxedo. The shooting technique used for this scene is a long shot where the audience will understand if Arthur is in a toilet and he is only dealing with Thomas Wayne. Occasionally, he also uses a medium close-up technique that only shows half the body and focuses on the actor's facial expressions and conversation.

Online at https://journal.universitasbumigora.ac.id/index.php/humanitatis/

DOI : https://doi.org/10.30812/humanitatis.v8i1.1436 


\author{
Thomas: "Can I help you?" \\ Arthur: "What? Yeah. No, I, I-" \\ Thomas: "You need to get in here or something?" \\ Arthur: "Dad. It's me." \\ Thomas: "Excuse me?" \\ Arthur: "My name is Arthur. I'm Penny's son. I, I know everything. And I don't want anything \\ from you. Well... maybe a hug."
}

Arthur's confession in the dialogue above shows that a person's ID works because he needs his life's necessities. The thing that drives ID is the unfulfilled wants and needs of life. This ID is the most important element for humans because human needs and desires must be fulfilled from birth. Even important needs such as parental love are the most important things in the formation of the structure of the human personality.

Thomas: "Jesus. You're the guy who came by my house yesterday."

Arthur: "Yes. But they wouldn't let me in, wouldn't let me see you. So, I came here. I have so many questions."

Thomas: "Look pal, I'm not your father. What's wrong with you?"

Arthur: "How do you know?"

Thomas: "Because you were adopted. And I never slept with your mother. What do you want from me, money?"

Arthur: "No. What? I wasn't adopted."

Thomas: "She never told you? Your mother adopted you after she worked for us. She was arrested when you were four years old and committed to Arkham State Hospital. She's batshit crazy."

Arthur: "No. No, I don't believe that."

Thomas: "I don't really give a shit what you believe. But if you ever come to my house again, if you ever talk to my son again, if I ever even hear about

you again, I'll kill you."

The dialogue above shows when Arthur says that he doesn't need money, but he just needs a father's hug and reassurance that he is the son of Thomas Wayne, who has never seen him since he was a child. When Arthur wants his ID needs to be fulfilled, he uses his Ego by asking Thomas Wayne directly about the truth of his life path. The way ID works in humans is very easy if the human can control it properly. However, humans will never be satisfied if what they need and want are not fulfilled, resulting in anger, distrust, and disappointment.

Arthur constantly couldn't believe what was said to Thomas as if it was a bitter reality in his life. His soul seemed to be shattered, but from this scene, the researcher said that from this scene, the next factor why Arthur could have DID. The point is that he wants to be like everyone else whose needs are met, but he never gets it.

Online at https://journal.universitasbumigora.ac.id/index.php/humanitatis/

DOI : https://doi.org/10.30812/humanitatis.v8i1.1436 

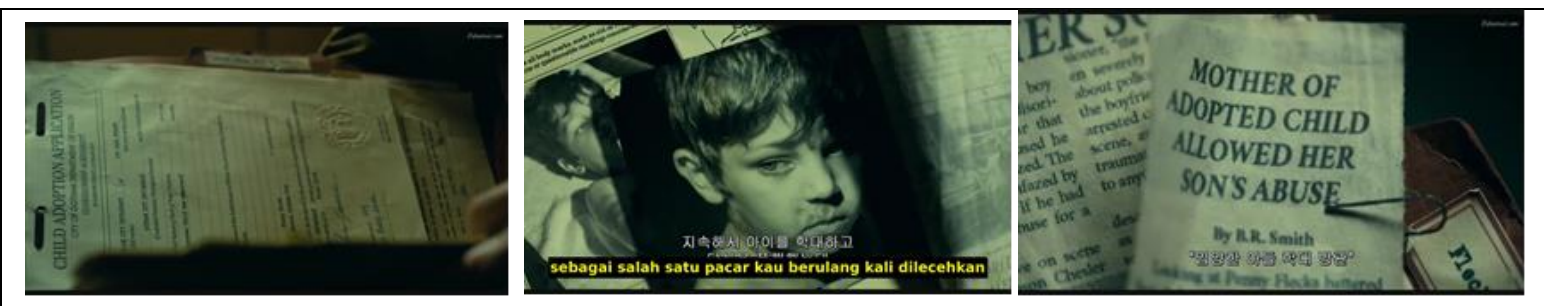

Figure 6: when Arthur finds out his past.

In the scene from 01:13:43 to 01:15:15, Arthur manages to get documents from Arkham hospital, where his mother was treated. Arthur was in a hospital hallway with drinking lighting. The hallway is quiet, and the shooting technique in this scene uses a high angle because Arthur, as the object, is shown lower, and the shooting process comes from the top of the stairs. The camera also uses close-up techniques several times to capture important parts, such as the writings on hospital documents.

Dr. Stoner: "We went over this, Penny. You adopted him. We have all the paperwork right here." Penny: "He had that all made up, so it stayed our secret."

In the dialogue above, the doctor tells Penny if Arthur is an adopted child. Arthur's disappointment grew even more, when he found out that the facts disclosed were true, coupled with the proof of the adoption letter attached to the document. Arthur's ID is getting out of control because he realizes that he has never received love from his parents since he was a child because he is an adopted child.

Dr. Stoner: "You also stood by as one of your boyfriends repeatedly abused your adopted son. And battered you."

Penny: "He didn't do anything to me. Or to my boy. Can I go now, I don't trust hospitals."

Penny: "I never heard him crying. Not once. He's always been such a happy little boy."

Dr. Stoner: "Penny, your son was found tied to a radiator in your filthy apartment, malnourished, with multiple bruises across his body and severe trauma to his head."

Penny: "That's not true. My apartment wasn't filthy. I keep a clean house."

Dr. Stoner: "And what do you have to say about your son?"

Penny: "I'm just glad I got to know him."

The dialogue above shows the key factors that cause Arthur to have a mental disorder, including DID. Arthur's trauma, abuse, and sexual harassment are factoring that shape Arthur's personality when he grows up. Some experts believed that childhood experiences and unconscious desires influence behavior. The conflicts and attacks from parents that occur during each of these stages can have a lifelong influence on a child's personality and demeanor as he grows up.

Online at https://journal.universitasbumigora.ac.id/index.php/humanitatis/

DOI $\quad$ : https://doi.org/10.30812/humanitatis.v8i1.1436 
The child will feel so depressed that he cannot control himself. Children who experience trauma in childhood will certainly have mental disorders because they must accept the pain until they grow up (Danese et al., 2020). Because this is the ID, Ego, superego in Arthur's body that runs unbalanced, he should still be able to balance the three.

The existence of bubbling emotions and disappointment because their needs and desires are not fulfilled impact the imbalance of the Id, Ego, and superego. What happens when the Id, Ego, and superego are unbalanced is that ID will take over everything because ID is based on the principle that if he needs something that makes him happy, then he has to do anything, even the worst thing, for his own satisfaction (Wang, 2020).

\section{CONCLUSION}

The Joker film, which was released in 2019, is indeed more focused on the life story of Arthur Fleck, which holds many mysteries that made him grow up with big question marks about his life. Arthur Fleck lives with mental disorders, one of which is dissociative identity disorder, which plays a major role in Arthur Fleck's life. DID is shown with a cutscene where Arthur Fleck begins to dare to kill people who make his life messy, dark, and meaningless. He even killed his own mother. It was because the person who experienced DID would be more satisfied if he managed to kill.

Based on the results of the study it was found that using the main theory of Sigmund Freud's psychoanalysis and Elizabeth Howell's DID theory, the result of this discussion is that when someone who has a disorder such as DID and that disorder is fatally committed to killing someone, then that person's ID, ego, and superego do not. work in balance because the ID that will dominate is greater so that the desire to kill arises which results in satisfaction for human ID. While the ego and superego here will not function as long as the ID continues to want what they need and want. ID, ego, and superego should be able to run in balance because humans not only live to fulfill their desires but also have to think about the consequences if humans only follow their desires without paying attention to existing norms and prohibitions. 


\section{REFERENCE}

Ahmed, A., \& Simmons, Z. (2013). Pseudobulbar affect: Prevalence and management. Therapeutics and Clinical Risk Management, 9(1), 483-489. https://doi.org/10.2147/TCRM.S53906

Danese, A., Smith, P., Chitsabesan, P., \& Dubicka, B. (2020). Child and adolescent mental health amidst emergencies and disasters. British Journal of Psychiatry, 216(3), 159-162. https://doi.org/10.1192/bjp.2019.244

Gupta, D. (2020). Synergy Between Teaching and Freud'S Structural Theory of Personality: Id, Ego and Superego. 17(6), 6723-6734.

Howell, E. F. (2012). Understanding and treating: Dissociative identity disorder: A relational approach. Understanding and Treating: Dissociative Identity Disorder: A Relational Approach, 1-308. https://doi.org/10.4324/9780203888261

Howell, E. F., \& Itzkowitz, S. (2016). The dissociative mind in psychoanalysis: Understanding and working with trauma. The Dissociative Mind in Psychoanalysis: Understanding and Working with Trauma, 74, 1-272. https://doi.org/10.4324/9781315679211

Lapsley, D. K., \& Stey, P. C. (2012). Id, Ego, and Superego. Encyclopedia of Human Behavior: Second Edition, October, 393-399. https://doi.org/10.1016/B978-0-12-375000-6.00199-3

Letterio, G., Bistas, K., Katehis, E., Patel, P., Azizi, H., Jolayemi, A., Letterio, G., Bistas, K., Katehis, E., Patel, P., Azizi, H., \& Jolayemi, A. (2020). Introjection and dissociative identity disorder: a case report. Journal of Psychology \& Clinical Psychiatry, 11(2), 51-54. https://doi.org/10.15406/jpcpy.2020.11.00670

Nugroho, M. B. (2013). a Multidisciplinary Handbook of Child and Adolescent Mental Health. In Journal of Chemical Information and Modeling (Vol. 53, Issue 9).

Rabiger, M., \& Hurbis-Cherrier, M. (2013). Directing: Film techniques and aesthetics: Fifth Edition. In Directing: Film Techniques and Aesthetics: Fifth Edition. https://doi.org/10.4324/9780203072387

Slochower, J. (2016). Taking the transference, reaching towards dreams: Clinical studies in the intermediate area. The International Journal of Psychoanalysis, 97(4), 1222-1226. https://doi.org/10.1111/1745-8315.12390

Trifu, S. (2019). Dissociative Identity Disorder. Psychotic functioning and impairment of growing-up processes. Journal of Educational Sciences \& Psychology, 9(2), 102-108.

Wang, J. (2020). An Analysis of Salieri in Amadeus from Freudian Personality Theory: Id, Ego, Superego. 3rd International Conference on Interdisciplinary Social Sciences \& Humanities (SOSHU 2020), Soshu, 78. https://doi.org/10.25236/soshu.2020.015

Online at https://journal.universitasbumigora.ac.id/index.php/humanitatis/

DOI : https://doi.org/10.30812/humanitatis.v8i1.1436 